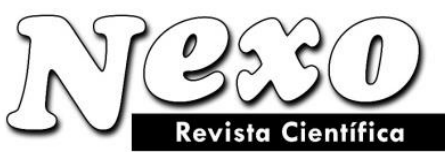

Vol. 34, No. 02, pp. 671-681/Junio 2021

\title{
Producing a superior genotype from agria potato cultivar using somaclonal variation
}

\section{Producción de un genotipo superior a partir de un cultivo de papa agria mediante la variación somaclonal}

\author{
Eshaghali Bayati ${ }^{1}$, Masoud Gomarian ${ }^{1}$, Hossein Mirzaie-Nodoushan ${ }^{* 2}$, Mehdi Changizi ${ }^{1}$, Shahab \\ Khaghani ${ }^{1}$ \\ ${ }^{1}$ Department of Agronomy and Plant Breeding, Arak Branch, Islamic Azad University, Arak, \\ Iran. \\ ${ }^{2}$ Biotechnology Department, Research Institute of Forests and Rangelands, Tehran, Iran. \\ *nodoushan2003@yahoo.com
}

(recibido/received: 29-diciembre-2020; aceptado/accepted: 22-febrero-2021)

\begin{abstract}
This study was performed to produce a superior genotype from Agria potato cultivar using somaclonal variation. Two leaf and meristem explants in combination with four doses of 2,4-D (0,2, 3 and $4 \mathrm{mg} / 1)$ were used for callus induction in a factorial model based on a completely randomized design with 3 replications. Results showed that the meristem explant, along with $3 \mathrm{mg}$ 2,4-D produced the most suitable calluses. In the mentioned regeneration media, the best calluses were regenerated and one of the regenerated genotypes, which was very different from the parent cultivar was selected. The regenerated genotype, was compared with the maternal genotype (Agria) and a control cultivar (Sante), in a field experiment based on a randomized complete block design with 3 replications. The results showed that in terms of most of the studied traits such as tuber weight per plant, stolon length, percentage of dry matter and percentage of starch, the new genotype was superior, compared to the parent cultivar and in terms of peel percentage and maturity date, the parental cultivar was superior. The results of the molecular comparison also showed that based on CBDP marker, both in terms of band number and band size, there were differences between the new genotype and the parental cultivar. In general, results showed that somaclonal variation can be an effective method to generate new genotypes with superior characteristics.
\end{abstract}

Keywords: CBDP marker, morphological traits, potato, somaclonal variation

\section{RESUMEN}

Este estudio se realizó para producir un genotipo superior de la variedad de papa Agria usando variación somaclonal. Se utilizaron dos explantes de hojas y meristemas en combinación con cuatro 
dosis de 2,4-D (0, 2, 3 y $4 \mathrm{mg} / 1)$ para la inducción de callos en un modelo factorial basado en un diseño completamente al azar con 3 repeticiones. Los resultados mostraron que el explante de meristemo, junto con $3 \mathrm{mg}$ de 2,4-D produjeron los callos más adecuados. En el medio de regeneración mencionado se regeneraron los mejores callos y se seleccionó uno de los genotipos regenerados, que era muy diferente al cultivar parental. El genotipo regenerado, se comparó con el genotipo materno (Agria) y un cultivar control (Sante), en un experimento de campo basado en un diseño de bloques completos al azar con 3 repeticiones. Los resultados mostraron que en términos de la mayoría de los rasgos estudiados, como peso del tubérculo por planta, longitud del estolón, porcentaje de materia seca y porcentaje de almidón, el nuevo genotipo fue superior, en comparación con la variedad parental y en términos de porcentaje de piel y madurez. fecha, el cultivar parental fue superior. Los resultados de la comparación molecular también mostraron que, según el marcador CBDP, tanto en términos de número de banda como de tamaño de banda, había diferencias entre el nuevo genotipo y el cultivar parental. En general, los resultados mostraron que la variación somaclonal puede ser un método eficaz para generar nuevos genotipos con características superiores.

Palabras clave: marcador CBDP, rasgos morfológicos, papa, variación somaclonal

\section{INTRODUCTION}

Potato is one of the most important tubular plant species, ranking fourth in terms of yield production after wheat, rice and corn. The area under cultivation of the species in Iran is 160,000 hectares (Mamnouie et al., 2016). One of the most productive potato cultivars in Iran is Agria cultivar, which is adapted with most parts of the world. Also, the cultivar is higher in terms of dry matter and starch than other high-yielding cultivars in the country. Therefore, the menmtioned cultivar is used more than other cultivars to produce various types of potato products such as chips, starch and other industrial products. Long growing season is one of the most important problems on Agria, which makes its water demand high (Muktar et al., 2015).

Classical potato breeding method is based on crossing between adapted high yielding cultivars and genotypes with desirable characteristics. Problems such as sterility, tetraploidy, and high levels of heterozygosity greatly affect the effectiveness of classical breeding methods on the species. Obviously, traditional breeding methods, apart from being time consuming, are not effective in many cases. Plant tissue culture is a complementary solution to overcome the problems (Rahnama et al., 2010). Plant tissue culture can be a good platform for conserving and preserving native or endangered species and genotypes as valuable sources of germplasm. When intra-species diversity is low, wild relatives, non-relative species, and even mutation techniques can be used to increase diversity. But in recent decades, a new source of usable diversity, namely the diversity resulted from cell and plant tissue cultures or somaclonal variation has attracted the attention of many researchers (Rabiee and Rashedi, 2011).

One of the most valuable sources to be used as explants for plant tissue culture is meristem cells. Cells of meristematic tissues have thin walls, large nucleus, and in most cases small vacuoles. Due to the rapid growth of the mentioned cells, vessels have not yet penetrated into this part and they do not have any infection with various viral or bacterial diseases (Shahpiri et al., 2004).

Due to the fact that somaclonal variation is more likely to occur due to mutations, appropriate assessment techniques should be used to detect the mutations in tissue culture. Numerous studies have been conducted to discover these kinds of variation, and the use of DNA markers due to their high accuracy and the possibility of examining a large number of samples in a short time is one of the most suitable methods. Using DNA markers in the study of somaclonal variation under different tissue culture conditions has shown 
a different band pattern among calluses. The number of subcultures is directly related to the rate of genetic changes in the calluses. On the other hand, the hormonal combination of the culture medium can cause genetic changes in the level of DNA molecules (Shoushtari et al., 2014).

Larkin and Skocraft (1981) observed some somaclonal variation in regenerated potato plants that had passed the callus stage. By performing the field experiments on regenerated plants Evans et al., (1988) found that not only yield but also traits such as maturity date, tuber traits such as shape, size, number and color changed. Shahpiri et al., (2004) studied tissue culture and somaclonal variation in different potato cultivars. They observed changes such as dehaploid, pantaploid, hexaploid, and octaploid levels of ploidy on callus cells, while no change was observed on the regenerated shoots derived from callus or directly regenerated from original cells.

The study of various factors in the induction of callus and the production of somaclonal variation has been on the agenda of many researchers (Ehsanpour et al., 2007). Karamzad et al., (2015) found many differences between their two types of explants (leaf and internode) used in their research, in which callus was produced, by examining different concentrations of 2,4-D and Kin on callus induction of Agria cultivar. They reported that different concentrations of the hormone used also had strong different effects on the callus production. There was also a large interaction between the types of explants and hormone levels.

On the induction of callus on potatoes, calluses and organisms can be induced using leaves and stems (Bhojwani, 1990). The effect of the culture medium and genotype used in regeneration of potato, leaf explant was also studied by Cardi et al. (1993), which indicated the significant effect of the culture medium and even the genotype used on the regeneration rate. Haque et al., (2009) study also found that different concentrations of 2,4-D and Kin contributed to the change in other traits. El-Sawy et al., (2007) concluded that if the callus produced by 2,4-D remained in this plant growth regulator for a long time, it would lose its regenerative power and could not be reproduced any longer. Callus induction has also been tested with concentrations of various combinations of growth regulators such as 2,4-D, NAA, and BA (Shirin et al., 2007).

The aim of this study was to produce new potato genotypes from Agria, using somaclonal variation, with better characteristics such as less water requirement than its parental genotype.

\section{MATERIALS AND METHODS}

Agria cultivar was used to induce genetic variation by using explants from leaf and stem internodes. For this purpose, mature leaves and stems with a thickness of 2 to $4 \mathrm{~mm}$ (from Agria cultivar) were used as the explants. First, the leaves and stem samples were rinsed with tap water and liquid soap for 15 minutes, placed in $70 \%$ ethanol for 10 seconds, and then rinsed three times with sterile distilled water. To culture the explants on a culture medium, strips of leaves along with main vein were cut to 0.5 to $0.8 \mathrm{~cm}$ by scalpel to be placed on the culture medium under sterile conditions. The stems were also cut into pieces about half a centimeter long, and each of the explants was placed on the MS culture medium with four replications. Regarding the MS culture medium used, in addition to $0.25 \mathrm{mg} / 1$ of Kin growth regulator, 2,4-D was used at different levels. Having two plant explants and 4 concentrations of 2,4-D, the experiment was performed as a factorial model based on a completely randomized design with 8 treatments. The treatments were studied in 4 replications (a total of 32 containers containing culture medium, in each of which 4 explants were cultured). The containers were placed in a growth chamber with 16 hours of light and 8 hours of darkness and temperature of $25^{\circ} \mathrm{C}$ and $17^{\circ} \mathrm{C}$ respectively. After one month, traits such as callus average diameter and percentage of callus formation were recorded. Effects of tissue type (leaves and stems) and 2,4-D concentrations (4, 3, 2 and $0 \mathrm{mg} / \mathrm{L})$ on callus production were assessed. The calluses representing structural diversity were regenerated and new potato genotypes were produced. Genotypes with good morphological diversity, suitable early establishment and growth were studied in greenhouse conditions. 
Further studies were carried out by transferring the regenerated plants to a field soil, establishment and propagation of the regenerated plants by micro-propagation techniques and subjecting to additional studies and comparisons at a molecular level with the parental cultivar.

\section{Morphological studies}

Regarding morphological studies, the regenerated plants were evaluated along with the parent cultivar and Sante cultivar as a control, in a field experiment with three replications in which at least three single plants were evaluated on each replication. The morphological features studied included number of very small tubers (smaller than $12 \mathrm{~mm}$ ), number of small tubers (between 12 and $20 \mathrm{~mm}$ ), number of semi-medium tubers (between 20 and $25 \mathrm{~mm}$ ), number of medium tubers (between 25 and $30 \mathrm{~mm}$ ), number of large tubers (30 to $35 \mathrm{~mm}$ ), number of very large tubers (larger than $35 \mathrm{~mm}$ ), total number of tubers per plant, days to $50 \%$ flowering, stolon length, total dry matter per plant, maturity date, percentage of dry matter, percentage of starch, tuber weight per plant, average depth of tuber eyes, average number of eyes per tuber, average number of main stems, average number of lateral stems, average number of branches, average number of leaves per plant and plant height. The data from this part of the study were analyzed based on a randomized complete block design with 3 replications.

\section{Molecular comparison}

Extraction of genomic DNA from Agria and the new genotype was performed by CTAB (Doyle \& Doyle, 1987) then quantity and quality of the DNA were evaluated using $0.8 \%$ agarose gel and Nano-drop device at 260 and $280 \mathrm{~nm}$.

Sequences of the used primers are presented in Table 1. After optimizing the conditions for polymerization and determining the annealing temperature of the selected primers, PCR reaction war performed on components including genomic DNA $(2 \mu \mathrm{l}), 10 \mathrm{ng} / \mu \mathrm{l}$ primers $(2 \mu \mathrm{l})$, deionized water $(6 \mu \mathrm{l})$, and $10 \mu \mathrm{l}$ of mastermix $(2 \mathrm{x})$ in the final volume of $20 \mu \mathrm{l}$. PCR reactions were performed by a T-100 Biorad thermocycler. The temperature program of each reaction included an initial denaturation at $95^{\circ} \mathrm{C}$ for 4 min, 35 cycles of denaturation at $94^{\circ} \mathrm{C}(1 \mathrm{~min})$, annealing at the optimized temperature for the related primer $(1 \mathrm{~min})$ and polymerization at $72^{\circ} \mathrm{C}(90 \mathrm{~s})$.

Table 1. Sequence and number of CBDP primers used in comparing Agria potato cultivar and a new genotype drived from Agria

\begin{tabular}{|c|c|}
\hline Sequence & Number \\
\hline TGAGCACGATCCAATAGC & 1 \\
\hline TGAGCACGATCCAATAAT & 2 \\
\hline TGAGCACGATCCAATACC & 3 \\
\hline TGAGCACGATCCAATAAG & 4 \\
\hline TGAGCACGATCCAATCTA & 5 \\
\hline TGAGCACGATCCAATCAG & 6 \\
\hline TGAGCACGATCCAATCGA & 7 \\
\hline TGAGCACGATCCAATCGG & 8 \\
\hline TGAGCACGATCCAATGAT & 9 \\
\hline TGAGCACGATCCAATGTT & 10 \\
\hline TGAGCACGATCCAATTGC & 11 \\
\hline TGAGCACGATCCAATATA & 12 \\
\hline TGAGCACGATCCAATGAG & 13 \\
\hline
\end{tabular}




\begin{tabular}{|c|c|}
\hline TGAGCACGATCCAATGCG & 14 \\
\hline TGAGCACGATCCAATTGA & 15 \\
\hline TGAGCACGATCCAATTCA & 16 \\
\hline TGAGCACGATCCAATTTG & 17 \\
\hline CTGAGCACGATCCAATAG & 18 \\
\hline CTGAGCACGATCCAATAC & 19 \\
\hline CTGAGCACGATCCAATAT & 20 \\
\hline CTGAGCACGATCCAATCA & 21 \\
\hline CTGAGCACGATCCAATCG & 22 \\
\hline CTGAGCACGATCCAATGG & 23 \\
\hline CTGAGCACGATCCAATGA & 24 \\
\hline CTGAGCACGATCCAATGT & 25 \\
\hline
\end{tabular}

\section{RESULTS AND DISCUSSION}

Results of the analysis of variance of the data obtained from the study of different types of explants and different concentrations of 2,4-D and their interaction on callus induction, callus diameter and callus weight are presented in Table 2. These traits were measured one month after culturing the explants. There is a significant difference between the two explants of leaf and meristem in terms of callus induction, callus diameter and callus weight at a probability level of $1 \%$. Also, the difference between 2,4-D concentrations was significant on callus induction at the $5 \%$ probability level and on the traits of callus diameter and callus weight at $1 \%$ probability level.

Table 2. Mean squares, resulted from analysis of variance of the traits measured on two cultured explants (leaf and meristem) using different concentrations of 2,4-D hormone

\begin{tabular}{|c|c|c|c|c|}
\hline Source of Variation & DF & Callus induction & Callus diameter & Callus weight \\
\hline Explant & 1 & $76.353^{* *}$ & $56.498^{* *}$ & $0.551^{* *}$ \\
\hline 2,4-D level & 3 & $21.620^{*}$ & $108.049^{* *}$ & $1.030^{* *}$ \\
\hline Interaction & 3 & $14.204 \mathrm{~ns}$ & $6.406^{* *}$ & $0.068^{* *}$ \\
\hline Error & 24 & 6.562 & 0.003 & 0.0001 \\
\hline CV (\%) & 11.05 & 1.14 & 2.08 \\
\hline *,**: significant at probability levels of 5 and 1 percent, respectively, ns: Non-significant \\
\hline
\end{tabular}

Means of explant levels showed that based on the three measured traits, meristem explants were superior compared to the leaf explant. Also $3 \mathrm{mg} / \mathrm{L}$ of 2,4-D had the greatest effect on the measured traits (Table $3)$.

Table 3. Mean classification of the studied factors on the measured traits on two cultured explants (leaf and meristem) using different concentrations of 2,4-D hormone

\begin{tabular}{|c|c|c|c|}
\hline Treatment & Callus induction (\%) & Callus diameter (mm) & Callus weight (mg) \\
\hline Explant & & & \\
\hline Leaf & $0.56 \mathrm{~b}$ & $4.17 \mathrm{~b}$ & $0.40 \mathrm{~b}$ \\
\hline Meristem & $3.65 \mathrm{a}$ & $6.83 \mathrm{a}$ & $0.66 \mathrm{a}$ \\
\hline $\begin{array}{c}2,4-\mathrm{D} \\
\text { Concentration }\end{array}$ & & & \\
\hline
\end{tabular}




\begin{tabular}{|c|c|c|c|}
\hline $0 \mathrm{mg} / \mathrm{L}$ & $0.00 \mathrm{c}$ & $0.00 \mathrm{c}$ & $0.00 \mathrm{c}$ \\
\hline $2 \mathrm{mg} / \mathrm{L}$ & $1.75 \mathrm{~b}$ & $7.24 \mathrm{~b}$ & $0.68 \mathrm{~b}$ \\
\hline $3 \mathrm{mg} / \mathrm{L}$ & $3.84 \mathrm{a}$ & $7.60 \mathrm{a}$ & $0.77 \mathrm{a}$ \\
\hline $4 \mathrm{mg} / \mathrm{L}$ & $2.83 \mathrm{a}$ & $7.18 \mathrm{~b}$ & $0.69 \mathrm{~b}$ \\
\hline
\end{tabular}

Means with similar letters in each column are not statistically different based on Duncan's multiple range test.

Classification of interaction effects of the explant levels with different concentrations of 2,4-D on the measured traits (Table 4) also showed that the meristem explant along with $3 \mathrm{mg} / \mathrm{L} \mathrm{2,4-D}$ had the best performance.

Table 4. Classification of the mean interactions of the studied treatments on the recorded traits on two cultured explants (leaf and meristem) using different concentrations of 2,4-D hormone

\begin{tabular}{|c|c|c|c|}
\hline Interaction effects & Callus induction $(\%)$ & Callus diameter $(\mathrm{mm})$ & Callus weight $(\mathrm{mg})$ \\
\hline Leaf $(0 \mathrm{mg} / \mathrm{L})$ & $0.00 \mathrm{~g}$ & $0.00 \mathrm{~g}$ & $0.00 \mathrm{~g}$ \\
\hline Leaf $(2 \mathrm{mg} / \mathrm{L})$ & $75 \mathrm{e}$ & $5.645 \mathrm{e}$ & $0.545 \mathrm{e}$ \\
\hline Leaf $(3 \mathrm{mg} / \mathrm{L})$ & $78 \mathrm{~d}$ & $5.775 \mathrm{~d}$ & $0.585 \mathrm{~d}$ \\
\hline Leaf $(4 \mathrm{mg} / \mathrm{L})$ & $25.71 \mathrm{f}$ & $5.287 \mathrm{f}$ & $0.485 \mathrm{f}$ \\
\hline Meristem $(0 \mathrm{mg} / \mathrm{L})$ & $0.00 \mathrm{~g}$ & $0.00 \mathrm{~g}$ & $0.00 \mathrm{~g}$ \\
\hline Meristem $(2 \mathrm{mg} / \mathrm{L})$ & $62.48 \mathrm{c}$ & $8.837 \mathrm{c}$ & $0.815 \mathrm{c}$ \\
\hline Meristem $(3 \mathrm{mg} / \mathrm{L})$ & $65.88 \mathrm{a}$ & $9.425 \mathrm{a}$ & $0.955 \mathrm{a}$ \\
\hline Meristem $(4 \mathrm{mg} / \mathrm{L})$ & $25.90 \mathrm{~b}$ & $9.075 \mathrm{~b}$ & $0.895 \mathrm{~b}$ \\
\hline $\begin{array}{l}\text { Means with similar letters in each column are not statistically different based on Duncan's } \\
\text { multiple range test. }\end{array}$
\end{tabular}

Since the optimal calluses were the ones produced on meristem culture, on the medium containing $3 \mathrm{mg}$ 2,4-D (Table 4), they were placed again in the culture medium containing regenerative hormones including BAP and IBA at a concentration of $1 \mathrm{mg} / \mathrm{L}$, and plantlets with main stems and roots were produced. It has been reported that meristem cells have a higher callus production ability, at the same time the callus vigurity is also higher (Rostami et al., 2012), which is confirmed by the results of this study. The production of regenerated plants by this method causes morphological changes in the plant and there is a possibility of changes in the genotype, which has been mentioned in other studies (Noormohammadi et al., 2017). Results of analysis of variance of the data recorded on Sante and Agria cultivars and the selected genotype in the field experiment are presented in Table 5.

Comparison of the studied morphological traits on the new genotype showed an increase by $67 \%$ in terms of the number of very small tubers, $29 \%$ on small tubers, $78 \%$ on semi-medium tubers and $15 \%$ on medium tubers, compared to the parental cultivar. Bolandi et al., (2010) reported that tubers weighted more than 10 grams were also superior in their performance. Another study reported that seed tubers between 35-55 mm in Morn and Cosmos cultivars were superior in all the studied traits compared to other smaller sizes (Rashidi et al., 2013).

In general, the genotype derived from Agria cultivar was $12 \%$ higher than the parent cultivar in terms of number of tubers per plant. Stolon length also increased by $4 \%$ compared to the maternal one, which confirmed the results on tuber number. It has been reported that longer stolon form more tubers on a potato plant. 
Table 5. Mean squares obtained from the analysis of variance of the measured traits on two potato cultivars and one new selected genotype.

\begin{tabular}{|l|c|c|c|c|}
\hline Character & Block & Treatment & Error & CV\% \\
\hline DF & 3 & 2 & 6 & - \\
\hline Very small tubers & $4.22 \mathrm{~ns}$ & $289.33^{* *}$ & 4.89 & 16.48 \\
\hline Small tubers & $4.22 \mathrm{~ns}$ & $197.33^{* *}$ & 8.89 & 15.42 \\
\hline Semi-medium tubers & $6.88 \mathrm{~ns}$ & $41.33^{* *}$ & 3.56 & 9.12 \\
\hline Medium tubers & $4.0 \mathrm{~ns}$ & $196.0^{* *}$ & 3.0 & 10.18 \\
\hline Large tubers & $1.88 \mathrm{~ns}$ & $41.33^{* *}$ & 4.25 & 7.40 \\
\hline Very large tubers & $3.3 \mathrm{~ns}$ & $81.3^{* *}$ & 3.3 & 7.50 \\
\hline Tubers per plant & $0.24 \mathrm{~ns}$ & $0.932^{* *}$ & 0.095 & 3.72 \\
\hline Depth of the eyes & $0.003 \mathrm{~ns}$ & $0.06 \mathrm{~ns}$ & 0.01 & 10.25 \\
\hline Eyes per tuber & $09.0 \mathrm{~ns}$ & $13.24 * *$ & 0.07 & 3.51 \\
\hline Main stems & $01.0 \mathrm{~ns}$ & $0.05 \mathrm{~ns}$ & 0.16 & 8.44 \\
\hline Lateral stems & $1.44 \mathrm{~ns}$ & $17.33^{* *}$ & 1.77 & 4.96 \\
\hline Leaf number & $4.22 \mathrm{~ns}$ & $3276.00^{* *}$ & 37.55 & 1.93 \\
\hline Leaf per plant & $288.8 \mathrm{~ns}$ & $3315845^{* *}$ & 955.55 & 0.98 \\
\hline Plant height & $249.22 \mathrm{~ns}$ & $61876.08^{* *}$ & 235.30 & 1.66 \\
\hline Day to 50\% flowering & $1.555 \mathrm{~ns}$ & $405.33^{* *}$ & 6.22 & 4.11 \\
\hline Stolon length & $2.305 \mathrm{~ns}$ & $255.25^{* *}$ & 2.80 & 1.82 \\
\hline Dry matter per plant & $4.701 \mathrm{~ns}$ & $745.47^{* *}$ & 1.95 & 0.53 \\
\hline Maturity date & $1.05 \mathrm{~ns}$ & $400.0^{* *}$ & 6.22 & 2.07 \\
\hline Dry matter percentage & $0.147 \mathrm{~ns}$ & $9.37^{* *}$ & 0.27 & 2.42 \\
\hline Starch percentage & $0.03 \mathrm{~ns}$ & $10.22^{* *}$ & 0.30 & 3.29 \\
\hline tuber weight per plant & $04.257 \mathrm{~ns}$ & $396.20 \mathrm{~ns}$ & 88.54 & 3.97 \\
\hline \multicolumn{2}{|c|}{ ns, $* *, *$ Non-significant and significant at the probability levels of 5 and 1 percent, } \\
\hline
\end{tabular}

Also, the tuber weight per plant increased by $8.7 \%$ on the new genotype, compared to the parental cultivar. Increasing the weight of the tubers would cause increment of average diameter of the tubers weight of the tubers and the yield per unit area (Mahmoudpour 2014, Bolandi et al., 2010). Therefore, it is likely that the yield of the generated genotype would be higher than the parental cultivar. Imani and Rasouli (2006) studied different sizes of seed tubers on the yield of Morn cultivar and showed that tuber yield would be increased by increment of seed tuber. A study has reported that growing lighter potato tubers allows germination to take place over a longer period of time, and plant buds produce weaker stems, smaller roots, and higher stem to root ratio. As a result, the number and weight of produced tubers in each plant would be decreased (Bolandi et al., 2010). It has also been shown that in order to achieve high yield, a suitable combination of cultivar, plant density and seed size should be considered. On the other hand, due to the fact that larger tubers produce more stems, as a result, the yield of plants from larger tubers is higher than that of smaller tubers (Siadat et al., 2000).

On the other hand, days to $50 \%$ flowering decreased by up to $11 \%$ in the new genotype compared to the parental cultivar. The growing season was similarly reduced by 7.5 percent, as well. Since there is a direct correlation between tuber setting and flowering date, when the flowering date is earlier, tuber setting also 
would be earlier. However, research has shown that temperature and other environmental stresses, such as lack of moisture, have a large effect on morphological characteristics of potato, including vegetative growth of the plant and especially during its flowering period (Escuredo et al., 2020; Rykaczewska, 2017; Hatfield and Prueger, 2015).

The dry matter content of the tubers in different potato cultivars is one of the important traits in determining the quality of the tubers, especially in chips processing industries. Cultivars with higher dry matter require less time to fry due to lower moisture content, in that case, they will have less time to absorb oil and change their color. Therefore, they are also better in terms of nutritional health. Considering $13.5 \%$ increment of dry matter of the new genotype, compared to the parental cultivar, it can be recommended for chips processing. Therefore, chips production efficiency on potatoes with higher dry matter, is higher than potatoes with lower dry matter (Balandi and Hamidi 2014). However, different climatic conditions have also shown interactions on the production of dry matter in different potato cultivars (Kooman et al., 1996; Daccache et al., 2012; Dahal et al., 2019; Write et al., 2017).

Table 6. Classification of the trait means recorded on two potato cultivars and one new selected genotype.

\begin{tabular}{|l|c|c|c|}
\hline Characters & New genotype & Agria (parent) & Sante (check) \\
\hline Very small tubers & $5 \mathrm{c}$ & $13 \mathrm{~b}$ & $22 \mathrm{a}$ \\
\hline Small tubers & $20 \mathrm{~b}$ & $12 \mathrm{c}$ & $26 \mathrm{a}$ \\
\hline Semi-medium tubers & $22 \mathrm{a}$ & $17 \mathrm{~b}$ & $23 \mathrm{a}$ \\
\hline Medium tubers & $25 \mathrm{a}$ & $14 \mathrm{~b}$ & $12 \mathrm{~b}$ \\
\hline Large tubers & $37 \mathrm{a}$ & $32 \mathrm{~b}$ & $17.5 \mathrm{c}$ \\
\hline Very large tubers & $20 \mathrm{c}$ & $29 \mathrm{a}$ & $24 \mathrm{~b}$ \\
\hline Tubers per plant & $8.8 \mathrm{a}$ & $7.8 \mathrm{~b}$ & $8.3 \mathrm{ab}$ \\
\hline Average eyes depth (mm) & $1.1 \mathrm{~b}$ & $1.2 \mathrm{ab}$ & $1.35 \mathrm{a}$ \\
\hline Average eyes per tuber & $8.8 \mathrm{a}$ & $8.7 \mathrm{a}$ & $5.6 \mathrm{~b}$ \\
\hline Average number of main stems & $4.8 \mathrm{a}$ & $4.8 \mathrm{a}$ & $5.0 \mathrm{a}$ \\
\hline Average number of lateral stems & $28.5 \mathrm{a}$ & $27.5 \mathrm{a}$ & $24.5 \mathrm{~b}$ \\
\hline Average number of leaf per main stem & $302 \mathrm{~b}$ & $299 \mathrm{~b}$ & $350 \mathrm{a}$ \\
\hline Average number of leaf per plant & $2770 \mathrm{~b}$ & $2770 \mathrm{~b}$ & $3850 \mathrm{a}$ \\
\hline Plant height (mm) & $994 \mathrm{a}$ & $989 \mathrm{a}$ & $776 \mathrm{~b}$ \\
\hline Days to 50\% flowering & $62 \mathrm{~b}$ & $70 \mathrm{a}$ & $50 \mathrm{c}$ \\
\hline Stolon length (mm) & $89.0 \mathrm{~b}$ & $85.5 \mathrm{c}$ & $100.7 \mathrm{a}$ \\
\hline Whole plant dry weight (gr) & $268.9 \mathrm{~b}$ & $273.4 \mathrm{a}$ & $247.8 \mathrm{c}$ \\
\hline Days to maturity & $120 \mathrm{~b}$ & $130 \mathrm{a}$ & $110 \mathrm{c}$ \\
\hline Dry matter (\%) & $22.65 \mathrm{a}$ & $19.95 \mathrm{~b}$ & $22.55 \mathrm{a}$ \\
\hline Starch (\%) & $18.01 \mathrm{a}$ & $14.9 \mathrm{c}$ & $16.9 \mathrm{~b}$ \\
\hline Tuber yield per plant (gr) & $246.5 \mathrm{a}$ & $226.6 \mathrm{~b}$ & $237.1 \mathrm{ab}$ \\
\hline Means with similar letters in each row do not have a statistically significant difference based \\
\hline \multicolumn{2}{|l|}{ on Duncan's multiple range test. } & \\
\hline
\end{tabular}

Starch quantity in potatoes, depending on the type of cultivar, is between 9 and 25 percent in fresh potatoes, and about 75 percent of the dry matter of potatoes is starch (Bhat, 2015). The percentage of starch in the new genotype increased by $21 \%$.

Peel percentage decreased in the new genotype by 2.3 percent. Since potato peel is often discarded as waste, this is important for the food industry to have varieties with less peel percentage (Toro-Sanchez et al., 2017). 
In addition to analyzing morphology of the new genotype, the two genotypes (Agria and its new progeny) were further studied in terms of variation at the molecular level with CBDP marker. Regarding CBDP molecular marker, same as RAPD, only one primer is used per PCR. These primers are based on CAAT box of plant gene promoters, and the reason for using these primers in this study was that the markers are somehow related to plant genome and are not as random as RAPD markers. Mechanism of band formation using these primers is based on the fact that some genes are on one strand of DNA and some genes are on the opposite strand. As a result, their transcription is opposite to each other, therefore, a CBDP primer that attaches to a CAAT box area in the proximity of two adjacent genes located on the two different strands of DNA, could polymerase the area between the promoter of one gene to the promoters of the next one. The results of the present study showed surprisingly that the genotype derived from the Agria cultivar was different in terms of both band number and band size for some CBDP primers. Any increase or decrease in nucleotides between the two genes or the variation created at the area between the two genes or the variation at the point of primers attachment, leads to the production of bands with different lengths. Therefore, any variation observed between the treatments using this marker can indicate a functional diversity at the gene level, therefore, the probability of finding a band correlated to a particular trait is high. In this study, the differences observed in the CBDP marker could also indicate a change in regulation of some genes. As mentioned, this marker is based on the gene-regulating regions in the promotor area. Somaclonal variation is a process that not only affects genes and ultimately plant morphology, but also alters gene expression and regulation.

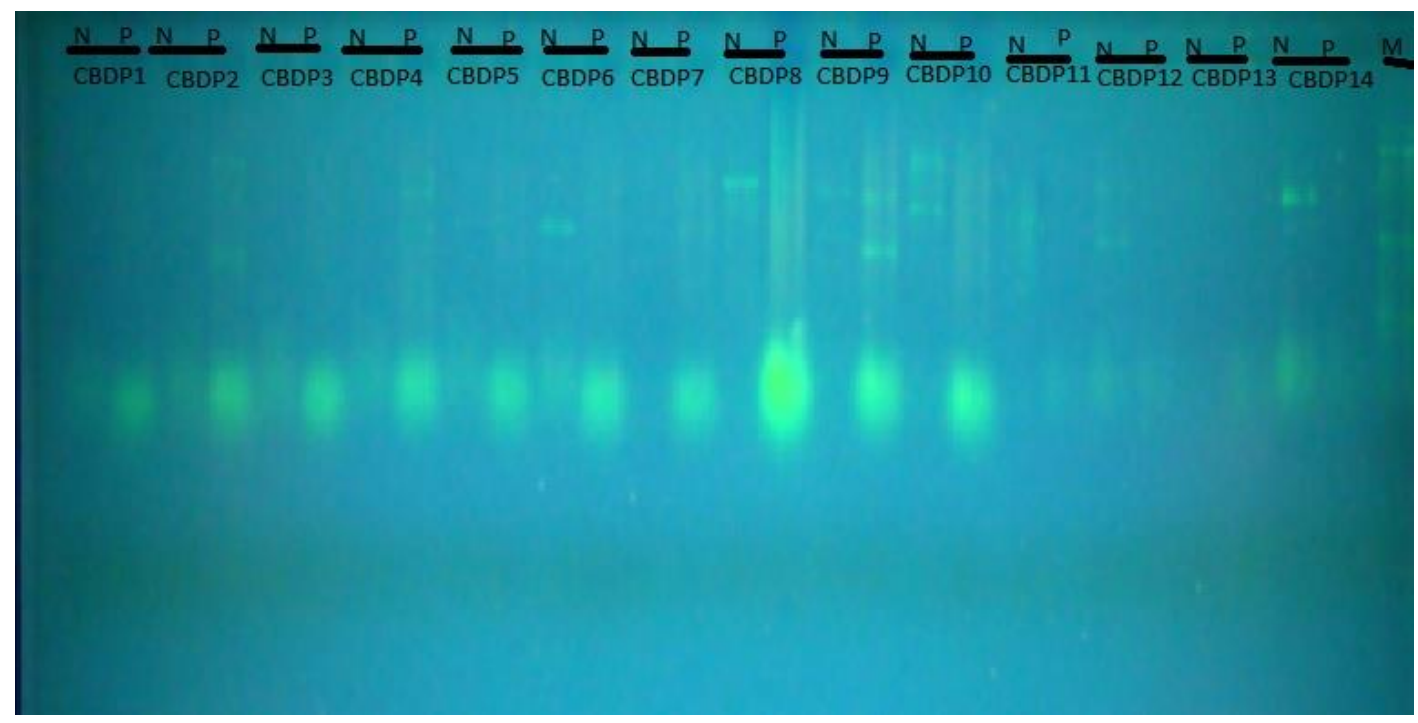

Fig.1. Gel profiles of some CBDP markers in Agria and progeny line introduced by somaclonal variation. Several CBDP primers presented different patterning band on Agria and the resulted progeny. N: Agria, P: progeny, M:size marker

\section{CONCLUSION}

In general, the results of morphological and molecular comparison of Agria cultivar with the new genotype showed that there was functional variation both at the phenotype and genotype levels. The new genotype was superior in quality compared to Agria, and in terms of quantity, its number and weight of tubers were higher than the parental cultivar. The genotype also showed a shorter maturity length than the parental cultivar, for which, it has less water demand. Due to the high price of mini-tubers and on the other hand the special conditions required for their cultivation, the cost of producing such seeds is high. Therefore, arrangements should be made so that while producing maximum yield, the produced tubers be as much as 
possible in the potato seed size, which according to the characteristics of the new genotype, the mentioned objective would be much easier and cost effective to achieve.

\section{REFERENCES}

Bhat, R., 2015. Varying amylose and total starch content in potato tubers derived from Finland and Sweden, Master thesis, Swedish University of Agricultural Science, Faculty of Natural Resources and Agricultural Science, Department of Food Science.

Bhojwani, S.S., 1990. Plant Tissue Culture: Applications and Limitations. Elsevier Science Publishers, Amsterdam, The Netherlands, 445.

Bolandi, A., Hamidi, H., Kefayi, S., 2010. The effect of plant distance and gland weight on the performance of Santa potato, Second National Conference on Agriculture and Sustainable Development (Opportunities and Challenges Ahead), Shiraz, Islamic Azad University, Shiraz Branch, Iran.

Cardi, I., Iannamico, V., D' Ambrosio, F., Flippone, E. and Lurqin, P.F., 1993. In vitro regeneration and cytological characterization of shoot from leaf explants of three accessions of Solanum commersoni. Plant Cell, Tissue and Organ Culture, 34: 107-114.

Daccache, A., Keay, C., Jones, R.J., Weatherhead, E.K., Stalham, M.A. and Knox, J.W., 2012. Climate change and land suitability for potato production in England and Wales; Impacts and adaptation. Journal of Agricultural Science, 150: 161177 .

Dahal, K., Li, X.Q., Tai, H., Creelman, A. and Bizimungu, B., 2019. Improving potato stress tolerance and tuber yield under a climate change scenario-a current overview. Front Plant Science, 10: 563.

Doyle, J.J. and Doyle, J.L., 1987. A rapid DNA isolation procedure for small quantities of fresh tissue. Phytochemical Bulletin, 19:11-15.

Ehsanpour, A.A., Madani, Sh. and Valian Brujeni, S., 2007. Detection of somaclonal variation in potato callus induced by uv-c radiation using RAPD-PCR Gen. Journal of Science, 3: 495-506.

El-sawy, A., Bekheet, S. and Aly, U.I., 2007. Morphological and molecular characterization of potato microtubers production on coumarin inducing medium. International Journal of Agriculture and Biology., 9 (5): 675-680.

Escuredo, O., Seijo-Rodríguez, A., Rodríguez-Flores, M.S., Meno, L. and Seijo, M.C., 2020. Changes in the morphological characteristics of potato plants attributed to seasonal variability. Agriculture, 10, 95.

Evans, D.A., Sharp, W.R. and Ammirato, P.V., 1988. Handbook of Plant Cell Culture. New York: Macmillan Publishing Company., 4:97- 132.

Haque, A.V., Samad, M.A. and Shapla, T.L., 2009. In vitro callus initiation and regeneration of potato. Bangladesh Journal of Agricultural Research, 34(3): 449-456.

Hatfield, J.L. and Prueger, J.H., 2015. Temperature extremes: Effect on plant growth and development. Weather Climate Extremes, 10: 4-10.

Imani, A. and Rasouli, M., 2006. The effect of seed size on yield and potato growth of Moran cultivar. Specialized ScientificResearch Letter of Agricultural Sciences, 12: 10-19.

Karamzad, J., Farshadfar, M., Zabarjadi, A.R. and Zulnoorian, H., 2015. Investigation of the effect of different concentrations of 2-4 D. and quinitin on the regeneration of potato plant (Solanum tuberosum L.) Vargaria Agria. Herbal Research, 28: 316-325.

Kooman, P.L., Fahem, M., Tegera, P. and Haverkort, A.J., 1996. Effects of climate on different potato genotypes 1. Radiation interception, total and tuber dry matter production. European Journal of Agronomy, 5:193-205. 
Larkin, P.J. and Scowcroft, W.R., 1981. Somaclonal variation - a novel source of variability from cell cultures for plant improvement. Theoretical and Applied Genetics, 60:197-214.

Mahmoudpour, A., 2014. Effects of different sizes of mini-tuber on yield and yield components of potato variety Agria. International Journal of Advanced Biological and Biomedical Research, 2: 1099 -1104.

Mamnouie, A., Karaminejad, M.R., Rashed Mohassel, M.R., and Shimi, P., 2016. Evaluation of some herbicides in controlling potato weeds (Solanum tuberosum L.) in Jiroft and Karaj, Quarterly Plant Protection, 30 (3).

Muktar, M.S., Lubeck, J., Strahwald, J. and Gebhardt, C., 2015. Selection and validation of potato candidate genes for maturity corrected resistance to Phytophthora infestans based on differential expression combined with SNP association and linkage mapping. Frontiers in Genetics, 6: 294.

NoorMohammadi, Z., Ghasempour, B. and Farahani, F., 2017. Investigation of somaclonal variation of plants regenerated from Aloe vera tissue culture. New Findings in Biological Sciences, 5: 72-81.

Rabiee, Z. Rashedi, H., Tahmasebi-Enferadi, S. and Akbari, A.A., 2011. Using Real time-PCR method to identify genetically engineered potato resistant to PVY virus compared to non-potato Transgenic, Journal of Food Science and Technology, 8:28.

Rahnama, H., Koohsari, Sh.M., Naderi-Meshkin, H. and Fahimi, H., 2010. Reconstruction with high frequency of separate components of intercropping, leaves and small tubers of potato (Solanum tuberosum L.). Iranian Biology, $25: 1$.

Rashidi, M., Rousta, H.R., Karimi, H.R., Alaei, H. and Tadayon-Nejad, M., 2013. Comparison of vegetative growth and minituber yield in three potato cultivars in aerospace and hydroponic systems classic (bed) and three different food solutions. Journal of Greenhouse Crops Science and Technology: 4(14): 73-80.

Rostami, R., Abarshamchi, P. and Lahouti, M., 2012. Callus induction and plant regeneration from potato meristem cultivation. Journal of Science of Tarbiat Moallem University, 10: 1011-1032

Rykaczewska, K., 2017. Impact of heat and drought stresses on size and quality of the potato yield. Plant Soil Environment, 63: $40-46$.

Shahpiri, A., Omidi, M., Ahmadian Tehrani, P. and Davoodi, D., 2004, Study of tissue culture and variety of sumaclon in potatoes, Journal of Agricultural Science, 2: 323-335.

Shirin, F., Hossain, M., Kabir, M.F., Roy, M. and Sarker, S.R., 2007. Callus induction and plant regeneration from internodal and leaf explant of four Potato (Solanum tuberosum L.) cultivars. World Journal of Agricultural Science. 3: 1 - 6.

Shoushtari, L., Atminan, A., Mehrafarin, A. and Ghaderi, A., 2014. Genetic and phytochemical evaluation of samples obtained from tissue culture of fennel (Foeniculum vulgar) in different hormonal concentrations. Journal of Medicinal Plants, $4: 52$.

Siadat, S.A., Hashemi Dezfuli, S., Sadeghzadeh Hamayati, S., Valizadeh, M., Noor Mohammadi, Q. and Fathi, Q., 2000. The effect of planting pattern and plant density on yield and some characteristics Endocrinology of the potato, three cultivars of potatoes in Ardabil region, Journal of Agricultural Sciences, 16 (12): 91-111.

Toro-Sánchez, C.L., Márquez- Ríos, E. and Ornelas-Paz, J.J., 2017. Phenolic compounds of potato peel extracts: their antioxidant activity and protection against human enteric viruses. Journal of Microbiology and Biotechnology, 27: 234 -241.

Wright, I.J., Dong, N., Maire, V., Prentice, I.C., Westoby, M., Díaz, S., Gallagher, R.V., Jacobs, B.F., Kooyman, R., and Law, E.A., 2017. Global climatic drivers of leaf size. Science, 357: 917-921. 